2016-3

\title{
Solving the Moro problem: legalizing the Bangsamoro peace process
}

Gene Carolan

Technological University Dublin, gene.carolan@tudublin.ie

Follow this and additional works at: https://arrow.tudublin.ie/aaschlawart

Part of the International Law Commons, Law and Politics Commons, and the Military, War, and Peace Commons

\section{Recommended Citation}

Carolan,G. (2016) "Solving the Moro problem: legalizing the Bangsamoro peace process," (2016) 8(3) Journal of Aggression, Conflict and Peace Research, 212. DOI 10.1108/JACPR-02-2016-0214

This Article is brought to you for free and open access by the Law at ARROW@TU Dublin. It has been accepted for inclusion in Articles by an authorized administrator of ARROW@TU Dublin. For more information, please contact arrow.admin@tudublin.ie, aisling.coyne@tudublin.ie, gerard.connolly@tudublin.ie. Funder: Maynooth University 


\section{Emerald Insight}

\section{Journal of Aggression, Conflict and Peace Research}

Solving the Moro problem: legalizing the Bangsamoro peace process

Gene Carolan

\section{Article information:}

To cite this document:

Gene Carolan , (2016),"Solving the Moro problem: legalizing the Bangsamoro peace process", Journal of Aggression, Conflict and Peace Research, Vol. 8 Iss 3 pp. 212 - 223

Permanent link to this document:

http://dx.doi.org/10.1108/JACPR-02-2016-0214

Downloaded on: 22 J une 2016, At: 03:34 (PT)

References: this document contains references to 55 other documents.

To copy this document: permissions@emeraldinsight.com

The fulltext of this document has been downloaded 6 times since 2016*

Access to this document was granted through an Emerald subscription provided by Token:J ournalAuthor:B0D8FCC2-

EF0E-49B6-804D-2C7FBD5BA1CD:

\section{For Authors}

If you would like to write for this, or any other Emerald publication, then please use our Emerald for Authors service information about how to choose which publication to write for and submission guidelines are available for all. Please visit www. emeraldinsight. com/ authors for more information.

\section{About Emerald www.emeraldinsight.com}

Emerald is a global publisher linking research and practice to the benefit of society. The company manages a portfolio of more than 290 journals and over 2,350 books and book series volumes, as well as providing an extensive range of online products and additional customer resources and services.

Emerald is both COUNTER 4 and TRANSFER compliant. The organization is a partner of the Committee on Publication Ethics (COPE) and also works with Portico and the LOCKSS initiative for digital archive preservation.

*Related content and download information correct at time of download. 


\section{Solving the Moro problem: legalizing the Bangsamoro peace process}

\section{Gene Carolan}

Gene Carolan is a PhD Candidate at the Department of Law, National University of Ireland Maynooth, Kildare, Ireland.
Received 9 February 2016

Revised 1 April 2016

3 April 2016

Accepted 3 April 2016

With thanks to Dr John Reynolds and Dr Noelle Higgins at Maynooth University for their invaluable advice and assistance, and the comments of the reviewers, which will be very helpful in refining the broader research from which this paper is drawn.

\begin{abstract}
Purpose - The purpose of this paper is to highlight the structural features that are proving central to the stability of the 2014 Comprehensive Agreement on the Bangsamoro between the Government of the Philippines and the Moro Islamic Liberation Front, and those features that were detrimental to its predecessors.

Design/methodology/approach - This paper adopts a legalization framework derived from the model presented by Abbott et al. The simplicity of Abbott et al.'s theory allows for variation in the agreements' text to be easily measured and compared. The inherent advantages of this model offset the difficulties in characterizing peace agreements under traditional legal methodologies, and reiterate the importance of legalized agreements in a conflict resolution context.

Findings - This paper finds that a more highly legalized approach to peace-making has resulted in greater agreement stability in the Philippines. More precise in detail and inclusive in scope, the legal nature of the 2014 Comprehensive Agreement has made it more responsive to the root causes of the conflict, and resilient to incidents that threatened to derail the peace process.

Practical implications - This case study bears valuable lessons for conflict zones the world over, particularly the troubled negotiations on Syria, and the crisis in Ukraine. The study: lends tentative support to Gopalan's claim that agreements that exemplify hard legalization are much more sustainable in the long run; stresses the advantages of inclusivity in agreement sustainability and stability; reiterates the importance of addressing the key issues relevant to the conflict if the process is to be sustainable, and; notes the limitations of the legalization framework, but presents the Philippine example as a blueprint for addressing various aspects of the Syrian and Ukrainian conflicts.

Originality/value - This is the first peer-reviewed analysis to explore the 2014 Comprehensive Agreement as a highly legalized conflict resolution instrument, and an adaptable template for peace agreement design generally.
\end{abstract}

Keywords Conflict resolution, International law, Ethnic conflict, Peace-making, Legalization,

Peace research

Paper type Research paper

\section{Introduction}

This paper employs a theory of legalization to critically evaluate the protracted peace process between the Government of the Republic of the Philippines (GRP) and Moro insurrectionists in Mindanao. Underpinning the study is a research question posed by legal and international relations scholars alike: whether there are certain features that are consistently attributable to sustainable processes of peace-making (Kittrie, 2003; Morriss, 1996; Fortna, 2003). Though an ample body of academic work in the field of conflict resolution has examined how belligerents might achieve victory (Wallensteen and Sollenberg, 1997, p. 342), how parties may be induced into negotiation (Walter, 1997), and how certain factors can influence the ultimate success of an agreement (Gleditsch and Beardsley, 2004; Bekoe, 2003; Stedman et al., 2002; Hartzell, 1999; 
Stedman and Rothchild, 1996), the role that the law can play in sustaining peace processes in the long term has been largely neglected. This analysis of the process's most significant agreements under a legalization framework - derived from the model presented by Abbott et al. (2000) highlights the legal features that are proving central to the stability of the 2014 Comprehensive Agreement on the Bangsamoro (CAB) and those that were detrimental to its predecessors. In doing so, it resituates the role of law in sustaining processes of peace.

The 40-year history of the conflict in the Mindanao region of the Philippines is particularly wellsuited for the purposes of this study. First, the Philippine peace process is testament to the claim that successful features in peace agreements can be borrowed from one process and applied to another (Bell, 2006, p. 410). The negotiations that culminated with the 2014 CAB were informed by provisions that had been successfully implemented in various other successful peace processes. For example, the negotiating parties were influenced by provisions pertaining to ethnic groups (the peace process between the Acehnese and the Malaysian state in Aceh), systems of governance (power sharing in Catalonia and Basque country, Spain), and third-party monitoring (as in South Sudan) (Mastura, 2013). The influence of the South Sudanese process is now readily observable in the adopted best practices of the International Monitoring Team operating in the Philippines, which has played a vital role in sustaining the parties' consensus over the past year. The Good Friday Agreement on Northern Ireland has also been acknowledged as a template for the warring parties' main grievances (Tisdall, 2013). The CAB provides for the establishment of an independent commission to advise on policing within the region, similar to the commission established by Section 9 of the Good Friday Agreement and its Annex on the Commission on Policing for Northern Ireland. The CAB's provisions on demobilization also obligate the parties to put their weapons "beyond use", a phrase which mirrors the language used by the parties to the peace process in Northern Ireland. While it would be counterproductive to condense the unique nature and peculiarities of any given conflict into a single, prototypical agreement (Omar, 2015), the Philippine experience demonstrates that an examination of successful agreements can have positive implications for peace processes globally: "Though we are not 'copy cats' of Northern Ireland, no doubt, we can draw concrete lessons from it if we are looking for a fresh wind blowing our own peace story [...]" (Mercado, 2011).

Second, the protracted peace process in Mindanao is ample evidence in itself of Gopalan's (2007a) claim that our ignorance in the field of agreement design has seen the repetition of the same mistakes in successive agreements (pp. 404-405); most notably a failure to address key issues and consult key actors in the conflict. The sustainability of the peace process has been repeatedly hampered by "the lack of participation of other stakeholders" (Santos, 2005a, p. 12), i.e., other Moro ethnic groups, Lumads (the non-Islamized indigenous tribal people of Mindanao), Christians, and key civil society actors (Paredes, 2015). This omission failed to generate any enthusiasm among the key stakeholders with regard to the implementation of possible solutions, and failed to adequately address the interests of these groups (Santos, 2005a, p. 12). Similarly, the issue of land ownership was repeatedly neglected over 30 years of renewed negotiations, despite being identified as the most likely source of post-conflict conflict in Mindanao (Oquist, 2002). These major issues have repeatedly proven themselves to be "major gaps" in the GRPMoro peace talks, and academics and practitioners alike can learn much from the negotiators' tendency to avoid these contentious topics. Thus, Mindanao - as was written of Northern Ireland before it - is an ideal region for a further study of agreement design (Mac Ginty et al., 2007, p. 3). As a conflict that was waged for 40 years, continuously fuelled by the same radical grievances, and fought by distinct ethno-religious identities, the Philippine experience of making peace in Mindanao is similarly suitable for a retrospective analysis of our past triumphs and failures alike (Morriss, 1996, p. 831).

\section{Legalization theory}

Legalization is a particularly appropriate lens under which the legal characteristics of peace agreements can be examined. Rather than viewing agreements as the product of either hard law or pure politics, Abbott et al.'s concept of legalization envisions a much broader spectrum of definition for legalized instruments that cannot be accurately categorized under traditional legal methodologies. Abbott et al. argue that a statute can attain legal status, or compensate for 
ambiguous legal form, by undergoing a distinct process of institutionalization, or legalization. A legalized statute, they argue, is comprised of three characteristics: obligation, precision and delegation.

Obligation refers to the extent to which an agreement's text establishes a normatively compelling and legally binding obligation on the parties. More specifically, obligation measures the degree to which the signatories' behaviour "is subject to scrutiny under the general rules, procedures, and discourse" of domestic and international law (Abbott et al., 2000, p. 401).

Precision entails the degree to which the provisions of the statute unambiguously prescribe the actions required, authorized or prohibited by the statute. Rules that are high on precision are usually "highly elaborated or dense, detailing conditions of application, spelling out required or proscribed behaviour in numerous situations" (Abbott et al., 2000, p. 413). Precision narrows the scope for self-serving interpretation by the contracting parties and limits the space for deviation from projected behaviour, characteristics that are of particular importance in a conflict resolution context. As Bell notes, "the language of peace agreements bears this out: they are written through with agreed numbers of armed forces, specification of weaponry, timetables, and even maps" (Bell, 2006, p. 396).

Finally, delegation refers to the third-party actors or institutions to which the authority to implement, interpret and enforce the rules of the agreement has been delegated. Highly delegated provisions ideally provide for interpretative authority to be vested in courts, arbitrators and mediatory or ad hoc tribunals, all of which may serve as dispute resolution mechanisms. Just as high levels of obligation and precision result in "the minimization of wiggle room to make excuses", so too do effective grants of delegation increase "the incentives for cooperation and the costs of opportunism" (Gopalan, 2007b, pp. 693-711).

In defining the complex process of legalization along three dimensions, Abbott et al.'s theory allows us to gauge the impact of highly obligatory, precise and delegative provisions within an agreement's text on the resulting peace process. The simplicity of this framework allows for comparative data to be drawn from the various agreements examined (Raustiala, 2005, p. 583). These inherent advantages offset the difficulties in characterizing agreements between state and non-state actors - such as those in the Philippines - under traditional concepts of law (Kahler 2000, p. 661), and "point to the importance of legalized models as an alternative to formal legal status" in a conflict resolution context (Bell, 2006, p. 375).

Agreements that rank high on all three dimensions are said to exemplify "hard legalization", i.e., those agreements that bear the character of hard law. Agreements that exhibit "soft legalization" are more akin to soft law, or "purely political" instruments. In their example, Abbott et al. point cite domestic legal systems "as prototypical of hard legalization" (Abbott et al., 2000, p. 402). They refer to a statute ratified by a legislative process which is legally binding on all of the nation's citizens (obligation), is clear and unambiguous in the behaviour that it requires or proscribes (precision) and is subject to judicial interpretation by the judiciary and enforcement by the organs of the police force (delegation). This study adopts their example as the standard for a highly legalized agreement. Conversely, an agreement that is largely rhetorical, lacking in substantive legal effect, and ambiguous with regard to its enforcement and interpretation is considered to be an example of soft legalization. Variation among agreements is not considered a binary choice between hard and soft legalization, but may depend on the extent to which the institutions established under the agreement are comprised, mandated and established, or the degree to which the implementation of the agreement is precisely laid out. Such variation is readily observable in the principle outputs of the Philippine peace process analysed herein.

It is thus unsurprising that both Bell and Gopalan have identified a positive correlation between hard legalization and sustainable processes of peace. Gopalan (2007a, b) for one, has repeatedly pointed to the link between hard legalization and the sustainability of agreements between ethnicdyads that are prone to conflict (p. 45; p. 726). However, highly legalized instruments can often be "a double-edged sword" (von Stein, 2008, p. 248). Explicitly defined agreements often require a sophisticated domestic institutional infrastructure (Kucik and Reinhardt, 2008, p. 501); they can prove inflexible in fluid situations (Koremenos et al., 2001, p. 793), and they often increase concerns about the parties' ability to comply when these adverse shocks occur 
(von Stein, 2008, p. 248). This concerns are particularly heightened in peacebuilding scenarios, where agreements must be able to address both short-term and long-term peace process goals (Bell, 2006, p. 393; von Stein, 2008, p. 248). This analysis of the conflict in Mindanao reaffirms Gopalan's study, however, and serves as a sterling example of a vicious conflict peacefully resolved, at a time when conflicts the world over are proving particularly resistant to negotiated settlement. It is to that example that we now turn.

\section{Conflict in Mindanao}

The root causes of the Mindanao conflict pertain to successive administrative policies of ethnic minoritization and systematic marginalization of the predominantly Muslim Moro people of the southernmost Philippines from the Christian-Filipino mainstream of Philippine society (Buendia 2005, p. 145). Christians, as 90 per cent of the population of the Philippines, have traditionally been advantaged by government policy, usually to the detriment of their Moro neighbours. Indeed, over the last 50 years, the predominantly Muslim region of Mindanao has lagged behind other urban centres in the Philippines in terms of socio-economic development (Quimpo 2001, p. 275). Today, provinces with a Muslim majority continue to rank among "the poorest, least educated, and most dangerous places in the Philippines" (Tuminez, 2008, pp. 122-3), with the little infrastructural and educational opportunities that these provinces receive "disproportionately going to serve Christian areas" (Ahmad, 2000, p. 13). Were it not for this uneven distribution of resources within majority-Muslim areas, "Mindanao provinces would not fare so poorly in terms of overall human development and one of the factors fuelling the conflict would be mitigated" (Cagoco-Guiam, 2003, p. 11).

In the late 1960s, the Moro began to chafe under "the perennial discrimination against [them] in many levels of the national life" (Majul, 1985, p. 31). In 1972, the Moro secessionist sentiment exploded into armed conflict when President Ferdinand Marcos imposed martial law to quell what he perceived as one of the biggest threats to national security, second only to the armed communist insurrection that was emerging at the same time (Quimpo, 2001, p. 275). Thus began a conflict that has persisted into the twenty-first century and outlived numerous peace accords in the process.

Though the Moro cause has been significantly advanced over the course of the decades-long conflict - initially under Nur Misuari"s Moro National Liberation Front (MNLF), and later, under the Moro Islamic Liberation Front (MILF), a splinter group of the original MNLF - the entrenched social, cultural, and religious cleavages that separate those of the Filipino nation and those of the Moro nation, or "Bangsamoro", ultimately caused "the extreme protraction of the peace process" (Santos, 2005a, p. 18). Negotiations have come to mirror "the complexity of the Philippines' physical geography - an archipelago with differing concentrations of conflict and social organization, where even the history of negotiations is disjointed and diverse" (Stankovitch and Carl, 1999, p. 5). This paper examines the most significant outputs of the peace process: the 1976 Tripoli Agreement, its successor, the 1996 Final Agreement, and the most recent CAB, signed in March 2014. As products of a formalized legal process that officially ended the conflict, these agreements satisfy the definition of peace agreements as accepted in the literature (Vinjamuri and Boesenecker, 2007, p. 6). It is to those agreements that we now turn.

\section{The Agreements}

\subsection{The Tripoli Agreement (1976)}

The Moro question was initially addressed by the Tripoli Agreement of 1976. The Agreement sought to establish Moro autonomy in the Southern Philippines, but the GRP would only accept a political solution that maintained the sovereignty and territorial integrity of the Philippine Republic. Facing mounting diplomatic pressure to accept some sort of compromise on the issue, the MNLF abandoned their strategic goal of secession and settled instead for autonomy within the Philippine Republic. In accepting these conditions, the MNLF was attempting to affect change through the same institutions that it had perceived as failing its constituency in the past, inadvertently paving the way for the GRP's unilateral implementation of the agreement on its own terms later. 
The Tripoli Agreement did appear to promise genuine autonomy for the Moros on paper, setting out executive and legislative organs, and judicial courts with the authority to enforce Shari'ah law. However, the Agreement postponed settlement on several issues to a later date, rendering implementation a difficulty from the outset. For example, the area of autonomy was to be empowered with its own administrative system and its own economic and financial system. In both instances, the relationship between these systems and the central government in Manila was to be discussed later, but without clarification on this issue, it was impossible for these institutions to function on the basis of the Tripoli Agreement alone. Such postponements rendered the Tripoli Agreement a process document at best, not a final and comprehensive peace agreement. In the absence of precise terms, the parties to the agreement could not meaningfully commit to anything of substantive legal effect; they were merely declaring mutually shared principles, ambitions and vagaries. The short-term gains of this tactic come at the cost of long-term peacebuilding, paving the way for claims of broken promises, and grounds for misunderstanding that could have been avoided altogether had the text been more highly legalized in accordance with Abbott et al.'s model. Instead, the imprecision that plagued the Tripoli Accord caused it to become "bogged down" in implementation, and eventually, it came apart.

Ironically, the provisions that were the most purposive and definite in tone were perhaps the most forcefully dismissive of conciliation between the parties. The limitations imposed by upholding the sovereignty and territorial integrity of the Philippine state denied the Moro people a role in the peace process. The Agreement had failed to empower the Moros with any form of political autonomy - particularly, the capacity to implement their side of the agreement. Instead, the Tripoli Agreement actually became a legitimate basis for GRP unilateralism with regard to the Moro conflict (Santos, 2005b, pp. 9-10).

4.1.1 Result. On the whole, the Tripoli Agreement was low on precision, obligation and delegation, and is an example of soft legalization. The agreement left too many details to be clarified at a later date for it to be considered a legalized basis for lasting peace. This omission merely postponed the inevitable disagreement between the parties and presented a quasiagreement in its stead. By paving the way for GRP unilateralism and failing to delegate any power away from state sovereignty, the agreement was open to subjective interpretation and could therefore be fit to any purpose that the GRP wished. Without any effective role in its implementation, the MNLF saw secession as the only viable alternative, and fighting broke out once more in 1977.

Despite failing to achieve lasting peace, the Tripoli Accord remains "the most significant juncture" in the GRP-MNLF negotiations (Santos, 2005a, p. 3). The agreement effectively changed the Moro problem from a question of independence to one of autonomy. From 1976 onward, all negotiations between the GRP and the alternating Moro groups took place within a unitary state model that preserved the sovereignty and territorial unity of the Philippine state. Accordingly, the Tripoli Agreement became the "main term of reference" between the GRP and the MNLF for the next 20 years (Santos, 2005a, p. 3).

\subsection{The Final Agreement (1996)}

It was not until 1996 that the GRP and MNLF appeared to turn a corner in their search for an end to the conflict. Following preliminary meetings in Libya in 1992, and West Java in 1993, the GRP and the MNLF agreed to hold formal peace talks to discuss the full implementation of the 1976 Tripoli Agreement, including "those portions of the Agreement left for further discussion [...]". The peace talks thus inherited the limitations imposed by the Tripoli Agreement, and reaffirmed the sovereignty, territorial integrity and Constitution of the Philippine state.

The Final Agreement was a much more precise document than its predecessor, providing for a Moro executive and legislature, and autonomous organs in educational and economic matters. However, the correlation between these institutions and the causes of the conflict was so weak that they did little to quell discontent in Mindanao. Autonomy was once more pushed to the forefront of the peace process, and its perception as a cure-all formula for the conflict in Mindanao proved much to the detriment of the other factors that had fuelled the conflict up unto 
that point: systematic policies of discrimination that were tied to issues of land ownership. For example, the Final Agreement vowed to make the new autonomous region the focus of intensive peace and development efforts. Public and private investments would be channelled into the region to spur economic activity, and a public body was tasked with attracting foreign investment into the Southern Philippines. Yet despite an enthusiastic response from the international community (Gutierrez, 1999, p. 66), these efforts failed to achieve the result that the agreement anticipated. Without confronting the systematic structures of inequality that underpinned Mindanao's chronic underdevelopment, economic investment could only do so much.

Despite the commitment that the MNLF displayed to peacemaking, problems with implementation proved, once more, "that there was nothing "final" in the Final Peace Agreement: it was just a prelude to more detours on the rocky road ahead" (Cagoco-Guiam, 2003, p. 4). Indeed, less than a month after its signature, the compromise enshrined in the Final Agreement was proving too good to be true. The presidential decree initiating the Agreement (Executive Order 371) was guilty of notable omissions and imprecisions, failing to specifically allocate funds for the transitional organs and displaying a lesser degree of precision than the peace agreement itself (Gutierrez, 1999, pp. 66-8). As a result, the key institutions of the autonomous region were created in an environment that restricted their overall impact and made them powerless: "[t]hey had very limited funding, no police powers, no control over national projects and programmes that were supposed to be within their remit [...]" (Gutierrez, 1999, pp. 66-7), and no function other than to make recommendations to the Office of the President.

4.2.1 Result. The Final Agreement is high on precision and medium-high on obligation, and is an example of hard legalization. Though the agreement's achievements were unprecedented at the time, and paved the way for a more comprehensive peace in the decades to come, they fell short of ensuring a permanent peace, however (Bertrand, 2000, p. 54). The Executive Order charged with implementing the initial phases of the agreement did not adopt as high a degree of legalization as the agreement itself did. A lesser degree of precision saw the omission of some notable details, including provision for the independent funding of the autonomous institutions. These omissions can be directly linked to the failures of the autonomous government to provide for its citizens.

These mistakes could have been avoided had the implementation of the Final Agreement not been so dependent on GRP legislation. As the process progressed, dissatisfaction grew within the MNLF over its perceived marginalization from the implementation of the agreement. It accused the GRP of implementing the agreement "unilaterally without completely and satisfactorily implementing the important socio-economic development requirements of the process" (Santos, 2005a, p. 16). As a result, "autonomy" became something of an unpleasant word in Muslim Mindanao: an empty political formula that had "failed to deliver genuine political power, representation, or economic development" (Tuminez, 2008, p. 124). Instead, the failings of the Final Agreement highlighted the need to focus attention on the root causes of the Mindanao conflict: the relationship between Christians, Muslims and other minority peoples, and land ownership.

\subsection{The Comprehensive Agreement on the Bangsamoro (2014)}

In an environment where the MNLF and the implementation of the Final Agreement were beginning to unravel, the MILF emerged as the new standard bearer of Moro aspirations. By virtue of a stop-start process of peace-making, and a proliferation of ceasefire agreements between the GRP and the MILF, the MILF and the Moro people became hopeful that "a better, and more effective agreement" than the 1996 settlement could be achieved (Bertrand, 2000, p. 50). These expectations effectively drained away the little support the MNLF had for the Final Agreement with the GRP, and ruled out the 1996 agreement as a comprehensive solution for the Moro people (Bertrand, 2000, p. 50).

GRP-MILF negotiations began to take shape immediately after the GRP had secured the 1996 peace with the MNLF. The MILF rejected the Final Agreement, rejecting autonomy as a cure-all for the Moro problem, and perceiving the agreement as a deviation from the original terms of the Tripoli accord (Santos, 2005a, p. 3). Negotiations were "glacial but steady" (ICG, 2008, p. 2), gradually moving forward on a step-by-step basis, with various ceasefire agreements becoming 
a precedent for further progress. Indeed, underpinning the MILF negotiating strategy was the belief "that each agreement represents a small and cumulative step forward" (ICG, 2004, p. 6). This belief aptly reflected the progress of the wider Philippine peace process: every agreement between the Moro revolutionary groups and the GRP - despite their many flaws discussed herein - marked another step towards a more comprehensive and final peace.

That comprehensive peace took shape in March 2014, when the GRP and MILF peace panels signed the $\mathrm{CAB}$. The $\mathrm{CAB}$ is the most expansive and inclusive of all the agreements that have documented the Moro conflict, and is rightly deserving of its title as a comprehensive settlement. The agreement is evidence of the knowledge both parties have gleaned from over 40 years of dearly bought lessons. The extensive consultation with Christian and Lumad communities undertaken by the GRP and MILF peace panels prior to the 2014 agreement is an implicit acknowledgement of how previously isolating these groups from the peace process had been a critical flaw. Indeed, inclusivity underpins the Moro homeland - or Bangsamoro - envisioned under the CAB. The agreement's Annex on Power Sharing provides that representation in the autonomous region's assembly shall reflect the diversity of the Bangsamoro, thereby taking non-Moro communities, women and settler communities into account.

The lessons learned from over 40 years of diplomatic engagement can also be seen in the CAB's recognition of the land issue. The agreement - unlike any of its predecessors - acknowledges the "unjust dispossession" of the Bangsamoro of their territorial and proprietary rights as a central issue underpinning the conflict. Not only does this provision officially address the contentious issue of land, it also provides a legal basis for the Moro people to seek reparation and further their own development where restoration of tenure is no longer possible. The reported systematic minoritization of Muslim land ownership over the course of the twentieth century had rendered the Moro homeland grossly underdeveloped; but this provision may yet serve as a basis for reversing that trend. In the absence of more precise provisions, this remains to be seen in practice, however.

There is also evidence to suggest that both parties have learned from the successes of agreements that have resolved conflict in other parts of the world, and have applied these lessons in turn to the Philippine experience. For example, the CAB's provisions on policing in the Bangsamoro, bear a striking resemblance to the provisions on policing and justice in the Good Friday Agreement on Northern Ireland. The CAB establishes an Independent Decommissioning Body - as in Northern Ireland - tasked with amassing the MILF's small arms and putting them "beyond use", a phrase that echoes the commitments of the parties to the peace process in Northern Ireland. The successful adaptation of these provisions in the Philippine context is just a glimpse of the potential knowledge we can garner from a broader analysis of peace processes worldwide.

The CAB concludes with a vow that this agreement will not be implemented unilaterally. This provision is not merely a political expression of good will - the body of text and annexes that comprise the CAB espouse the value of partnership between the GRP and the MILF and give effect to a range of political mechanisms that necessitate their cooperation. This move away from unilateral implementation is indicative of an overarching shift in the way the conflict in Mindanao has come to be perceived. Autonomy is no longer seen as the sole solution to the conflict, but it is an effective means for the Bangsamoro to address the issues that fuelled it for 40 years. The most sustainable solution lies in addressing those issues - land ownership, wealth sharing, the rights of indigenous and minority peoples and their relationship with the Moro people - and the CAB is an unprecedented accomplishment in that regard.

4.3.1 Result. Ultimately, the $\mathrm{CAB}$ is high on precision and high on obligation when compared to its predecessors, and is an example of hard legalization. Granted, many of the institutions envisioned by the CAB are not entirely novel or creative departures from those that came before; autonomous executive, legislative and judicial organs had been included in the earlier Final Agreement, but did not result a final peace. This suggests that the shift towards legalizing the CAB has had a significant impact on sustaining the relevant parties' consensus, thereby encouraging expectations that this agreement may finally bring about peace in Mindanao. Not only have the omissions and failings of previous agreements been addressed in the CAB - an inclusion that is significant in and of itself - but moreover, they have been considered in detail. 
It would be unwise to conclude on the ultimate success of the CAB before seeing how these details play out in practice - the Final Agreement teaches us a valuable lesson in that regard. Moreover, as Quilala (2015) predicted (p. 104), the Aquino administration's failure to ratify the CAB before the Philippine Congress in February 2016 continues to cast a long shadow over the peace process. Nevertheless, there is room for cautious optimism that the level of precision evident in the CAB may yet sustain some of the same provisions that bore huge potential for peace in the past.

\section{Conclusions}

An analysis of the GRP-Moro peace process thus reaffirms Gopalan's claim: agreements that exemplify hard legalization and espouse legal certainty are much more sustainable in the long run. Agreements that are high on precision, in particular, encourage more stable and durable settlements that legally bind the parties to a greater extent than their imprecise counterparts. For example, the low-precision evident in the Tripoli Agreement rendered it an uncertain roadmap to peace at best. Its ambiguity with regard to the key issues caused the consensus between the MNLF and the GRP to become unstable when these issues had to be discussed in more detail. Similarly, the Final Agreement, though wholly more precise than its predecessor, came apart due to a lack of precision in the Executive Order charged with implementing the agreement.

Though the $\mathrm{CAB}$ was also guilty of postponing its finer details to an uncertain date in the future, imprecision was mitigated by the precision evident throughout the rest of the CAB. Unlike its predecessors, the CAB avoids unilateral means of implementation and precisely provides for structures of cooperation. This allows both parties to settle their disputes within the legal limits of the peace process as partners in peace-making. It is submitted that these precisely worded provisions alleviated the worries of the MILF, who were able to anticipate with certainty what they would get out of the agreement and change their behaviour accordingly. This highlights the impact of legal language on the behaviour of former belligerents, and reiterates the importance of legalized instruments as means to resolve conflict.

The stop-start processes in Syria and Ukraine could learn much from this legalized approach to peace-making. Both conflicts have been subject to conflict resolution instruments that have been legally binding in the abstract, but dead letter in practice (Pauwelyn and Andonova, 2015), In Ukraine, for example, the Minsk II Protocol failed to specify exactly where the "truce line" separating the belligerent parties lay, an omission that paved the way for the skirmishes that soon followed after the conclusion of the agreement (Kinstler, 2015). Similarly, UN Security Resolutions 2254 and 2165 on Syria stressed the need for monitoring mechanisms with regard to a cessation of hostilities and the delivery of humanitarian aid, respectively, but failed to specify exactly how these bodies might function in practice. This emphasis on being legally binding in form but not in substantive content has done nothing to move these conflicts towards a satisfactory outcome, and suggests that both conflicts could benefit from a highly legalized process setting out precise and practical follow-up procedures, including periodic reviews and the imposition of sanctions and exacting deadlines (Pauwelyn and Andonova, 2015; Shabaneh, 2013).

The conclusion of the CAB also stresses the importance "of open, structured and inclusive negotiations to end conflict" (Vatikiotis, 2014). The GRP-Moro peace process has charted a broad spectrum of inclusivity, and the stability of its most significant outputs can also be charted on this same spectrum, with exclusive and divisive negotiations often producing a haphazard peace. In the case of Tripoli, the exclusive negotiations between Misuari's MNLF and the GRP provided little room for dissenting voices in the MNLF to have their say on Moro aspirations, and engendered a split in the MNLF ranks. The Final Agreement also came under fire for its "much vaunted 'consensus and consultations"', which "were largely limited to the negotiating parties, except for a few token efforts to communicate with civil society organisations" (Stankovitch and Carl, 1999, p. 8). The CAB, in contrast, was informed by a consultative process that engaged the stakeholders who would be affected by the creation of the Bangsamoro, and this is evident in the resulting text. The $\mathrm{CAB}$ explicitly recognizes the rights and traditions of indigenous peoples, and provides for their representation in the Bangsamoro assembly. As a result of the CAB's inclusivity, the agreement takes a comprehensive account of the broader social problems 
that have beset Mindanao: chronic underdevelopment, the distribution of wealth and resources; and not just the ethno-nationalistic cause of the Moro people which had dominated the focus of previous agreements.

The need for open and inclusive negotiations has not been lost on peacemakers in Ukraine and Syria, where regional and international stakeholders have been recognized as central to the success of any long-term solution. However, negotiations remain beset by differences at the most radical level. In the aftermath of the Minsk II Protocol, officials in Kiev declined to meet face-to-face with pro-Russian elements, labelling them as "terrorists" (Bovt, 2015). Despite an unprecedented effort to include and unite, proximity talks on Syria in early 2016 have also been marred by the omission of Kurdish forces, key militant opposition groups and women. Both of these conflicts could benefit from the inclusive example set by the CAB, which has empowered the MILF as a bulwark against the spread of Islamic fundamentalism in the Southern Philippines, and has provided a vital role for women and minority peoples in sustaining the peace process.

The importance of precision and inclusion came together to great effect in the form of the CAB, and thereby revealed another key lesson in peace-making - that sustainable processes of peace must address all the key issues relevant to the conflict. While this may seem obvious, the desire to postpone or evade difficult and contentious issues has been a glaring omission from over 40 years of peace-making in the Philippines, and is a marked feature of conflicts the world over. The CAB, however, explicitly addresses the issues that originally ignited the conflict in Mindanao and repeatedly fuelled it, despite several negotiated agreements: land ownership, religion, and the relationship between Moros, Christians and Lumads who comprise Filipino society. The CAB directly addresses these key issues and brings the relevant stakeholders that have created such violent conflict together, in a bid to pacify these volatile components.

A comprehensive account of the key issues underpinning the conflict in Syria appears to be a distant prospect at this moment, but peace-making efforts in Ukraine could be revitalized by recourse to the Philippine example. To date, the Minsk Protocols have failed to address the key issue of Ukraine's sovereignty and territorial integrity, and the political process envisioned under Minsk II has repeatedly stalled because the text did not set out the institutions necessary to sustain it. The Ukrainian crisis is thus particularly analogous to the Philippine example, which posed similar questions about territorial integrity, regional autonomy and ethnic differences. As a highly legalized and precise document that stands in stark contrast to the Minsk Protocols, the CAB could serve as a template to this seemingly intractable conflict that runs the risk of enduring permanently.

The Ukrainian and Syrian examples also highlight the limitations of this study and the limited utility of highly legalized agreements in a conflict resolution context, however. It is broadly recognized that a successful peace agreement usually reflects the unique peculiarities of the conflict it aims to resolve, and in that regard, "no one pattern suits all" (Hottinger, 2006, p. 49). The conflicts in both Ukraine and Syria possess distinct characteristics that make them ill-suited to a settlement in the vein of the CAB. Given their strategic geopolitical location, both countries have presented themselves as landscapes for competing international interests to act upon, and for proxy forces to operate in. This has complicated the formulation of a coordinated international and inclusive national approach to resolving the conflicts in a manner that the Mindanao conflict did not.

Furthermore, the rigid limitations often imposed by hard law could potentially frustrate the operation of highly legalized agreements in both Syria and Ukraine. Kucik and Reinhardt observe that highly legalized systems require highly sophisticated domestic legal and political institutions, significant resources and the administrative expertise to make them work (2008:501). Unlike the Philippine state, Ukraine and Syria are experiencing periods of violent political upheaval, and arguably in the latter case, collapse. As such, it is questionable whether either possess the institutional capacity to implement a rigidly defined comprehensive settlement. The Philippine experience does, however, offer some general direction on how to go about realizing that settlement, and amassing the relevant stakeholders necessary to make it work.

It remains to be seen whether the CAB's text, which bears so much promise, can stand the test of time. The agreement was recently celebrated upon the second anniversary of its conclusion, and in those two years, it has weathered the political fallout of a deadly "mis-encounter" between Philippine military and MILF forces in Mamasapano. But this analysis, like many others, must 
concede than an examination of any peace process 'is bound to be a snapshot of "a work in progress"' (Simmons and Dixon, 2006, p. 6). Concerns remain about how the politics of inclusion espoused by the CAB will play out in practice (Paredes, 2015, p. 175), and the causal roots of violence may yet persist in Mindanao even if the agreement is successfully implemented (Layador, 2015, pp. 87-8). However, the CAB's outright rejection of unilateralism and its broadly inclusive process of peace-making has sustained the parties' commitment to a peaceful solution to date despite these challenges, and evidences how the stakeholders have learned from previous shortcomings. Should the CAB endure, it will continue to offer hope to the Moro and Filipino peoples trying to escape decades of conflict, and may serve as inspiration to those trying to escape a similar plight in Ukraine and Syria.

\section{References}

Abbott, K., Keohane, R., Moravcsik, A., Slaughter, A.M. and Snidal, D. (2000), "The Concept of legalization”, International Organization, Vol. 54 No. 3, pp. 401-19.

Ahmad, A. (2000), "Class and colony in mindanao", in Guiterrez, E. (Ed.), Rebels, Warlords and Ulama: A Reader on Muslim Separatism and the War in Southern Philippines, Institute for Popular Democracy, Quezon, pp. 4-20.

Bekoe, D. (2003), "Toward a theory of peace agreement implementation: the case of liberia", Journal of Asian \& African Studies, Vol. 38 Nos 2-3, pp. 256-94.

Bell, C. (2006), "Peace agreements: their nature and legal status", The American Journal of International Law, Vol. 100 No. 2, pp. 373-412.

Bertrand, J. (2000), "Peace and conflict in the Southern Philippines: why the 1996 peace agreement Is Fragile", Pacific Affairs, Vol. 73 No. 1, pp. 37-54.

Bovt, G. (2015), "No peace for Ukraine without US", The Moscow Times, 17 February, available at: www. themoscowtimes.com/opinion/article/no-peace-for-ukraine-without-u-s/516081.html (accessed 30 May 2016).

Buendia, R.G. (2005), "The state-Moro armed conflict in the Philippines - unresolved national question or question of governance?”, Asian Journal of Political Science, Vol. 13 No. 1, pp. 109-38.

Cagoco-Guiam, R. (2003), "Negotiations and detours: the rocky road to peace in Mindanao", in Stankovitch, M. (Ed.), The Mindanao Peace Process: A Supplement to Compromising on Autonomy, Accord Conciliation Resources, London, pp. 37-54.

Fortna, V.P. (2003), "Scraps of paper? Agreements and the durability of peace", International Organization, Vol. 57 No. 2, pp. 337-72.

Gleditsch, K.S. and Beardsley, K. (2004), "Nosy neighbours: third-party actors in central American conflicts", Journal of Conflict Resolution, Vol. 48 No. 3, pp. 379-402.

Gopalan, S. (2007a), "From Darfur to Sinai to Kashmir: Ethno-religious conflicts and legalization”, Buffalo Law Review, Vol. 55 No. 2, pp. 403-56.

Gopalan, S. (2007b), "India-Pakistan relations: legalization and agreement design”, Vanderbilt Journal of Transnational Law, Vol. 40 No. 3, pp. 687-726.

Gutierrez, E. (1999), "The politics of transition”, in Stankovitch, M. (Ed.), Compromising on Autonomy Mindanao in Transition, Accord Conciliation Resources, London, pp. 66-75.

Hartzell, C. (1999), "Explaining the stability of negotiated settlements to intrastate war", Journal of Conflict Resolution, Vol. 43 No. 1, pp. 3-22.

Hottinger, J.T. (2006), "The darfur peace agreement - expectations unfulfilled”, in Simmons, M. and Dixon, P. (Eds), Peace by Piece - Addressing Sudan's Conflicts, Accord Conciliation Resources, London, pp. 46-9.

International Crisis Group (2004), "Southern Philippines backgrounder: terrorism and the peace process", Asia Report No. 80, Brussels, 13 July.

International Crisis Group (2008), "The Philippines: the collapse of peace in Mindanao", Asia Report No. 83, Jakarta and Brussels, 23rd October.

Kahler, M. (2000), "The causes and consequences of legalization”, International Organization, Vol. 54 No. 3 , pp. 661-83. 
Kinstler, L. (2015), "Way station for war", Foreign Policy, 12 February, available at: http://foreignpolicy.com/ 2015/02/12/way-station-for-war-kiev-ukraine-minsk/ (accessed 17 February 2015).

Kittrie, O.F. (2003), "More process than peace: legitimacy, compliance, and the oslo accords", Michigan Law Review, Vol. 101 No. 6, pp. 1661-714.

Koremenos, B., Lipson, C. and Snidal, D. (2001), "The rational design of international institutions", International Organization, Vol. 55 No. 4, pp. 761-99.

Kucik, J. and Reinhardt, E. (2008), "Does flexibility promote cooperation? An application to the global trade regime", International Organization, Vol. 62 No. 3, pp. 477-505.

Layador, M.A.R.L.G. (2015), "Falling short in security sector governance (SSG): clans and auxiliaries in Maguindanao contributing to un-peace?", Philippine Political Science Journal, Vol. 36 No. 1, pp. 73-93.

Mac Ginty, R., Muldoon, O.T. and Ferguson, N. (2007), "No war, no peace: Northern Ireland after the Agreement", Political Psychology, Vol. 28 No. 1, pp. 1-11.

Majul, C.A. (1985), The Contemporary Muslim Movement in the Philippines, Mizan Press, Berkeley, CA.

Mastura, I. (2013), "Philippines: Bangsamoro, a triumph of western diplomacy?", Small Wars Journal, Vol. 9 No. 1, available at: http://smallwarsjournal.com/jrnl/art/philippines-bangsamoro-a-triumph-of-westerndiplomacy/(accessed 31 March 2016).

Mercado, O.J. (2011), "Negotiating the Good Friday Agreement”, GMA News, 11 October, available at: www. gmanetwork.com/news/story/235009/opinion/blogs/negotiating-the-good-friday-agreement/ (accessed 28 October 2015).

Morriss, D. (1996), "From war to peace: a study of cease-fire agreements and the Evolving Role of the United Nations", Virginia Journal of International Law, Vol. 36 No. 4, pp. 801-932.

Omar, M. (2015), "Islam is a religion of peace", Foreign Policy, 9 November, available at: http://foreignpolicy.com/ 2015/11/09/islam-is-a-religion-of-peace-manal-omar-debate-islamic-state/ (accessed 10 November 2015).

Oquist, P. (2002), "Mindanao and beyond: competing policies, protracted peace process and human security", Philippines report, United Nations Development Programme 5th Peace Assessment Mission, Manila.

Paredes, O. (2015), "Indigenous vs native: negotiating the place of Lumads in the Bangsamoro homeland", Asian Ethnicity, Vol. 16 No. 2, pp. 166-85.

Pauwelyn, J. and Andonova, L. (2015), "A 'Legally Binding Treaty' or not? The Wrong Question for Paris Climate Summit”, European Journal of International Law: Talk!, 4 December, available at: www.ejiltalk.org/alegally-bindingtreaty-or-not-the-wrong-question-for-paris-climate-summit/ (accessed 5 December 2015).

Quilala, D.F. (2015), "The Philippines in 2014: unmasking the daang matuwid”, Philippine Political Science Journal, Vol. 36 No. 1, pp. 94-109.

Quimpo, N.G. (2001), "Options in the pursuit of a Just, comprehensive, and stable peace in the Southern Philippines", Asian Survev, Vol. 41 No. 2, pp. 271-89.

Raustiala, K. (2005), "Form and substance in international agreements", American Journal of International Law, Vol. 99 No. 3, pp. 581-614.

Santos, S.M. Jr (2005a), "Delays in the peace negotiations between the Philippine Government and the Moro Islamic Liberation Front: causes and prescriptions," Working Papers, No. 3, East-West Centre, Washington, DC.

Santos, S.M. Jr (2005b), "Evolution of the armed conflict on the Moro front," A Background paper submitted to the Human Development Network Foundation, Quezon City.

Shabaneh, G. (2013), Geneva II Middle East Peace Conference, Al Jazeera Centre for Studies, 4 December, available at: http://studies.aljazeera.net/ResourceGallery/media/Documents/2013/12/4/201312492123 299580Geneva\%20II\%20Middle\%20East\%20Peace.pdf (accessed 9 February 2016).

Simmons, M. and Dixon, P. (2006), "Introduction", in Simmons, M. and Dixon, P. (Eds), Peace by Piece - Addressing Sudan's Conflicts, Accord Conciliation Resources, London, pp. 6-9.

Stankovitch, M. and Carl, A. (1999), "One step towards peace: the 'Final Peace Agreement' in Mindanao", in Stankovitch, M. (Ed.), Compromising on Autonomy - Mindanao in Transition, Accord Conciliation Resources, London, pp. 5-8. 
Stedman, S. and Rothchild, D. (1996), "Peace operations: from short-term to long-term commitment", International Peacekeeping, Vol. 3 No. 2, pp. 17-35.

Stedman, S., Rothchild, D. and Cousens, E. (Eds) (2002), Ending Civil Wars: The Implementation of Peace Agreements, Lynne Rienner Publishers, Boulder.

Tisdall, S. (2013), "Philippines moves close to historic peace deal with Islamist rebels", The Guardian, 13 February, available at: www.theguardian.com/world/2013/feb/13/philippines-peace-deal-islamist-rebels (accessed 30 May 2015).

Tuminez, A.S. (2008), "Neither sovereignty nor autonomy: continuing conflict in the Southern Philippines", American Society of International Law, Vol. 102 No. 1, pp. 122-5.

Vatikiotis, M. (2014), "Why peace in Muslim Mindanao and how it was reached matters", Minda News, 28 January, www.mindanews.com/mindaviews/2014/01/28/commentary-why-peace-in-muslim-mindanaoand-how-it-was-reached-matters (accessed 30 May 2016).

Vinjamuri, L. and Boesenecker, A.P. (2007), "Accountability and peace agreements: mapping trends from 1980 to 2006", Centre for Humanitarian Dialogue, Geneva.

von Stein, J. (2008), "The international law and politics of climate change ratification of the United Nations Framework convention and the kyoto protocol”, Journal of Conflict Resolution, Vol. 52 No. 2, pp. 243-68.

Wallensteen, P. and Sollenberg, M. (1997), "Armed conflicts, conflict termination and peace agreements, 1989-96", Journal of Peace Research, Vol. 34 No. 3, pp. 339-58.

Walter, B. (1997), "The critical barrier to civil war settlement", International Organisation, Vol. 51 No. 3, pp. 335-64.

\section{Further reading}

Abuza, Z. (2003), Militant Islam in Southeast Asia: Crucible of Terror, Lynne Rienner Publishers, Boulder.

Buendia, R.G. (2002), "A re-examination of ethnicity and secessionist movements In the Philippines and Indonesia: the Moros and acehnese", Philippine Political Science Journal, Vol. 23 No. 46, pp. 3-48.

George, T.G.S. (1980), Revolt in Mindanao: The Rise of Islam in Philippine Politics, OUP, Oxford.

Kaufman, S.J. (2011), "Symbols, frames, and violence: studying ethnic war in the Philippines", International Studies Quarterly, Vol. 55 No. 4, pp. 937-58.

Majul, C.A. (1988), "The Moro struggle in the Philippines", Third World Quarterly, Vol. 10 No. 2, pp. 897-922.

Tan, A. (2003), "The indigenous roots of conflict in southeast Asia: the case of Mindanao", in Ramakrishna, K. and Seng Tan, S. (Eds), After Bali: The Threat of Terrorism in Southeast Asia, Institute of Defence and Strategic Studies, Singapore, pp. 97-117.

\section{About the author}

Gene Carolan is a John and Pat Hume Scholar with the Maynooth University Department of Law, Ireland. His doctoral thesis critically evaluates the protracted peace processes in Sierra Leone, Sudan and the Philippines, with a view to identifying the legal provisions that have proven central to successful peace agreements. In 2015, Gene was awarded a Certificate in Mediation by the European Security and Defence College, and he has previously presented on aspects of his research at the Queen's University Belfast, the University of Ulster's Transitional Justice Institute, the Irish Centre for Human Rights at NUI Galway and the Edward M. Kennedy Institute for Conflict Intervention at Maynooth University. Gene Carolan can be contacted at: gene.carolan.2009@mumail.ie

For instructions on how to order reprints of this article, please visit our website:

www.emeraldgrouppublishing.com/licensing/reprints.htm

Or contact us for further details: permissions@emeraldinsight.com 